\title{
Dinitrogen $\left(\mathrm{N}_{2}\right)$ pulse emissions during freeze-thaw cycles from montane grassland soil
}

\author{
Xing $\mathrm{Wu}^{1,2} \cdot$ Zhe Chen $^{1,3} \cdot$ Ralf Kiese $^{1} \cdot$ Jin Fu ${ }^{1,4} \cdot$ Silvia Gschwendter ${ }^{5} \cdot$ Michael Schloter $^{5,6} \cdot$ Chunyan Liu $^{7}$. \\ Klaus Butterbach-Bahl ${ }^{1} \cdot$ Benjamin Wolf ${ }^{1} \cdot$ Michael Dannenmann $^{1}$ (B)
}

Received: 11 February 2020 / Revised: 27 April 2020 / Accepted: 3 May 2020 / Published online: 23 May 2020

(C) The Author(s) 2020

\begin{abstract}
Short-lived pulses of soil nitrous oxide $\left(\mathrm{N}_{2} \mathrm{O}\right)$ emissions during freeze-thaw periods can dominate annual cumulative $\mathrm{N}_{2} \mathrm{O}$ fluxes from temperate managed and natural soils. However, the effects of freeze thaw cycles (FTCs) on dinitrogen $\left(\mathrm{N}_{2}\right)$ emissions, i.e., the dominant terminal product of the denitrification process, and ratios of $\mathrm{N}_{2} / \mathrm{N}_{2} \mathrm{O}$ emissions have remained largely unknown because methodological difficulties were so far hampering detailed studies. Here, we quantified both $\mathrm{N}_{2}$ and $\mathrm{N}_{2} \mathrm{O}$ emissions of montane grassland soils exposed to three subsequent FTCs under two different soil moisture levels (40 and 80\% WFPS) and under manure addition at $80 \%$ WFPS. In addition, we also quantified abundance and expression of functional genes involved in nitrification and denitrification to better understand microbial drivers of gaseous $\mathrm{N}$ losses. Our study shows that each freeze thaw cycle was associated with pulse emissions of both $\mathrm{N}_{2} \mathrm{O}$ and $\mathrm{N}_{2}$, with soil $\mathrm{N}_{2}$ emissions exceeding $\mathrm{N}_{2} \mathrm{O}$ emissions by a factor of 5 30. Increasing soil moisture from 40 to $80 \%$ WFPS and addition of cow slurry increased the cumulative FTC $\mathrm{N}_{2}$ emissions by $102 \%$ and $77 \%$, respectively. For $\mathrm{N}_{2} \mathrm{O}$, increasing soil moisture from 40 to $80 \%$ WFPS and addition of slurry increased the cumulative emissions by $147 \%$ and $42 \%$, respectively. Denitrification gene cnorB and nos $Z$ clade I transcript levels showed high explanatory power for $\mathrm{N}_{2} \mathrm{O}$ and $\mathrm{N}_{2}$ emissions, thereby reflecting both $\mathrm{N}$ gas flux dynamics due to FTC and effects of different water availability and fertilizer addition. In agreement with several other studies for various ecosystems, we show here for mountainous grassland soils that pulse emissions of $\mathrm{N}_{2} \mathrm{O}$ were observed during freeze-thaw. More importantly, this study shows that the freeze-thaw $\mathrm{N}_{2}$ pulse emissions strongly exceeded those of $\mathrm{N}_{2} \mathrm{O}$ in magnitude, which indicates that $\mathrm{N}_{2}$ emissions during FTCs could represent an important $\mathrm{N}$ loss pathway within the grassland $\mathrm{N}$ mass balances. However, their actual significance needs to be assessed under field conditions using intact plant-soil systems.
\end{abstract}

Keywords Freeze-thaw cycles $\cdot$ Dinitrogen $\cdot$ Nitrous oxide $\cdot$ Denitrification $\cdot$ Functional genes $\cdot$ Soil moisture $\cdot$ Fertilization

Zhe Chen contributed equally to this work.

Electronic supplementary material The online version of this article (https://doi.org/10.1007/s00374-020-01476-7) contains supplementary material, which is available to authorized users.

Michael Dannenmann

michael.dannenmann@kit.edu

1 Institute for Meteorology and Climate Research, Atmospheric Environmental Research (IMK-IFU), Karlsruhe Institute of Technology (KIT), 82467 Garmisch-Partenkirchen, Germany

2 State Key Laboratory of Urban and Regional Ecology, Research Center for Eco-Environmental Sciences (RCEES), Chinese Academy of Sciences, Beijing 100085, China

3 School of Ecology and Environmental Science, Yunnan University, Kunming 650500, China
4 Sino-France Institute of Earth Systems Science, Laboratory for Earth Surface Processes, College of Urban and Environmental Sciences, Peking University, Beijing 100871, China

5 Research Unit Comparative Microbiome Analysis, Helmholtz Zentrum München, 85764 Neuherberg, Germany

6 Chair for Soil Science, Technische Universität München, 85354 Freising, Germany

7 State Key Laboratory of Atmospheric Boundary Layer Physics and Atmospheric Chemistry (LAPC), Institute of Atmospheric Physics, Chinese Academy of Sciences, Beijing 100029, China 


\section{Introduction}

In the last century, human activities have more than doubled the amount of reactive nitrogen $(\mathrm{Nr})$ in the biosphere, mainly through fossil fuel combustion and fertilization (Fowler et al. 2013). Among the multiple nitrogen (N) transformation pathways, microbial denitrification, the reduction of nitrogen oxides $\left(\mathrm{NO}_{3}{ }^{-}\right.$and $\left.\mathrm{NO}_{2}{ }^{-}\right)$to $\mathrm{NO}$ and $\mathrm{N}_{2} \mathrm{O}$, and ultimately $\mathrm{N}_{2}$ gases under anaerobic conditions, is the most important mechanism responsible for the permanent removal of $\mathrm{Nr}$ in terrestrial ecosystems (Kulkarni et al. 2008; Groffman 2012; Butterbach-Bahl et al. 2013). Moreover, it can be considered as a significant source or sink process for the potent atmospheric greenhouse gas $\mathrm{N}_{2} \mathrm{O}$ (Chen et al. 2015). Despite its importance, denitrification is poorly understood at all scales ranging from soil micropores to global (Galloway et al. 2008; Butterbach-Bahl et al. 2013), mainly due to its notoriously high spatiotemporal variability and the fundamental difficulty in measuring soil $\mathrm{N}_{2}$ emissions (Kulkarni et al. 2008; Sgouridis and Ullah 2015). Therefore, a reliable estimate of the denitrification rates as well as of the ratios of the different $\mathrm{N}$ gases produced during denitrification is essential to improve our ability to fully account for the $\mathrm{N}$ fluxes and pools in different ecosystems at multiple scales (Groffman et al. 2006; Qu et al. 2014; Sgouridis and Ullah 2015).

Soil freeze-thaw cycles (FTCs) occur regularly in ecosystems at mid- to high latitude as well as high altitude. Changing climate conditions are likely to decrease the duration of the snow period and the thickness of snowpack (Henry 2008), which in turn could lead to an increase in the frequency of FTCs (Matzner and Borken 2008). Freeze-thaw cycles were shown to trigger pulse $\mathrm{N}_{2} \mathrm{O}$ emissions both in laboratory(e.g., Nyborg et al. 1997; Goldberg et al. 2008; WagnerRiddle et al. 2008) and field experiments (e.g., Wolf et al. 2010; Németh et al. 2014; Morse et al. 2015). The underlying mechanisms include a strong stimulation of denitrification due to liberation of $\mathrm{C}$ and $\mathrm{N}$ substrates in combination with anaerobic conditions, or a physical entrapment and release of previously produced gases when ice or snow cover thaw (Mørkved et al. 2006; de Bruijn et al. 2009; Kim et al. 2012; Risk et al. 2013; Wu et al. 2014; Wertz et al. 2016). However, due to the methodological difficulties in the quantification of $\mathrm{N}_{2}$ that further rise under conditions of frozen soil, very little is known on effects of soil FTCs on $\mathrm{N}_{2}$ fluxes, the $\mathrm{N}_{2} / \mathrm{N}_{2} \mathrm{O}$ emission ratio and total denitrification losses (Nyborg et al. 1997; Wagner-Riddle et al. 2008). Currently, available approaches for quantifying the gaseous end-products $\left(\mathrm{N}_{2}+\right.$ $\mathrm{N}_{2} \mathrm{O}$ ) of denitrification are limited and can be classified into (1) the acetylene blockage method, which exploits acetylene inhibition of the reduction of $\mathrm{N}_{2} \mathrm{O}$ to $\mathrm{N}_{2}$ (Groffman et al. 2006; Felber et al. 2012), (2) the ${ }^{15} \mathrm{~N}$ gas flux technique, which requires ${ }^{15} \mathrm{NO}_{3}{ }^{-}$application to soil followed by the measuring of ${ }^{15} \mathrm{~N}_{2} \mathrm{O}$ and $/$ or ${ }^{15} \mathrm{~N}_{2}$ in the gaseous end-products
(Kulkarni et al. 2014; Sgouridis and Ullah 2015), and (3) the gas-flow soil core (GFSC) method, which allows the direct simultaneous measurement of $\mathrm{N}_{2} \mathrm{O}$ and $\mathrm{N}_{2}$ fluxes from soil cores when the soil atmosphere is replaced by a mixture of $\mathrm{He} /$ $\mathrm{O}_{2}$ (Butterbach-Bahl et al. 2002; Wang et al. 2011). Among these approaches, the GFSC method has the advantage that it does not require addition of isotopically labeled substrates or inhibitors to the soil (Chen et al. 2015; Wen et al. 2016).

Soil moisture has been identified as one of the crucial drivers of temporal variability of soil-atmosphere $\mathrm{N}$ gas fluxes through the regulation of oxygen availability and the soil microbes' respiration chain (Wu et al. 2010; Friedl et al. 2016). While the stimulating effects of soil moisture on denitrification and associated $\mathrm{N}$ trace gas fluxes for unfrozen soils have been very well documented, there is less information on the effects of different soil moisture levels on pulse $\mathrm{N}_{2} \mathrm{O}$ emissions during freeze-thaw periods (Teepe et al. 2004; Kim et al. 2012). Wu et al. (2014) indicated that a threshold value of soil moisture could exist that needs to be surpassed to trigger $\mathrm{N}_{2} \mathrm{O}$ peaks during thawing. On the other hand, non-significant $\mathrm{N}_{2} \mathrm{O}$ emissions during thawing periods under very moist conditions might be partly due to the further reduction of $\mathrm{N}_{2} \mathrm{O}$ to $\mathrm{N}_{2}$ by denitrification because of complete denitrification under strictly anaerobic conditions (de Bruijn et al. 2009; Wu et al. 2014). Based on a meta-analysis, Gao et al. (2018) found that the increase of soil moisture during FTCs can lead to increasing losses of $\mathrm{N}_{2} \mathrm{O}$ due to the enhanced substrate release from the ice-induced physical soil disturbances. Another key driver for soil $\mathrm{N}$ gas fluxes is the availability of $\mathrm{N}$, as in most studies, $\mathrm{N}$ fertilizer input has been shown to stimulate nitrification and denitrification as well as gaseous $\mathrm{N}$ emissions (Qu et al. 2014; Kuang et al. 2019).

Montane grasslands, receiving high $\mathrm{N}$ inputs in the form of urine and animal manure, are widespread in Central Europe and store large amounts of soil organic $\mathrm{N}$ (Wiesmeier et al. 2013). In these ecosystems, manuring is often taking place in autumn, winter, and early spring as the storage capacity for slurry is limited and requires field application of slurry also during the non-growing season. However, during these periods several FTCs may occur. So far, however, no study directly quantified both $\mathrm{N}_{2}$ and $\mathrm{N}_{2} \mathrm{O}$ losses from montane grasslands, which prevents the closing of $\mathrm{N}$ balances on the ecosystem scale and hampers the development of sound management strategies targeted to improve slurry $\mathrm{N}$ use efficiency.

Besides the direct quantification of $\mathrm{N}$ gas emission rates, also the abundance of nitrifiers and denitrifiers as well as the expression of genes driving both processes can provide insights into the regulation of $\mathrm{N}_{2} \mathrm{O}$ production rates and its reduction to $\mathrm{N}_{2}$ (Chen et al. 2015; Pan et al. 2018). A growing number of studies has been pointing out that $\mathrm{N}_{2} \mathrm{O}$ fluxes are linked to the expression rates of genes triggering nitrification and denitrification, but the reported results are not consistent (Henderson et al. 2010; Németh et al. 2014; Chen et al. 2015). 
For example, Henderson et al. (2010) did not detect significant relationships between the abundance of denitrifiers and the expression levels of the related functional genes on $\mathrm{N}_{2} \mathrm{O}$ emissions in agricultural soils. Chen et al. (2015) found that nos $\mathrm{Z}$ gene expression was closely related to $\mathrm{N}_{2}$ rather than $\mathrm{N}_{2} \mathrm{O}$ emission in montane grassland soils. The effects of cold temperatures on the abundance of nitrifiers and denitrifiers as well as the expression of the related genes have recently been examined in different soils with, however, no parallel measurements of both $\mathrm{N}_{2} \mathrm{O}$ and $\mathrm{N}_{2}$ fluxes (Jung et al. 2011; Nemeth et al. 2014; Wertz et al. 2016). Németh et al. (2014) reported that $\mathrm{N}_{2} \mathrm{O}$ emissions were inversely related to the nos $\mathrm{Z}$ transcript levels (i.e., the genes involved in $\mathrm{N}_{2} \mathrm{O}$ reduction to $\mathrm{N}_{2}$ in denitrification) in agricultural soils during FTCs. Generally, difficulties in bridging spatial scales between gene analyses in small soil samples and $\mathrm{N}$ gas flux measurements at larger scales impair our understanding of relationships between expression of functional nitrifier and denitrifier genes and $\mathrm{N}_{2} \mathrm{O}$ and $\mathrm{N}_{2}$ fluxes.

Therefore, the main objectives of this study were to (1) quantify FTC $\mathrm{N}_{2} \mathrm{O}$ and $\mathrm{N}_{2}$ emissions and (2) to explore the effects of soil moisture and fertilization on the abundance and activity of nitrifier and denitrifier communities and the associated $\mathrm{N}_{2} \mathrm{O}$ and $\mathrm{N}_{2}$ fluxes during soil FTCs. We hypothesized that FTCs would cause peak emissions of both $\mathrm{N}_{2} \mathrm{O}$ and $\mathrm{N}_{2}$ mainly triggered by denitrification with $\mathrm{N}_{2}$ losses exceeding $\mathrm{N}_{2} \mathrm{O}$ losses. Furthermore, we expected that slurry application increases FTC $\mathrm{N}$ gas pulse emissions and that at higher soil moisture, the importance of $\mathrm{N}_{2}$ would increase over the importance of $\mathrm{N}_{2} \mathrm{O}$. Additionally, we hypothesized that $\mathrm{N}$ gas dynamics would be closely linked to the expression pattern of genes triggering denitrification. To test these hypotheses, we conducted a laboratory incubation experiment exposing a montane grassland soil to FTC with measurements of $\mathrm{N}_{2}$ / $\mathrm{N}_{2} \mathrm{O}$ emissions by use of the He soil core technique accompanied by measurements of abundance and activity of nitrifers/denitrifers, as well as supporting parameters such as soil dissolved organic and inorganic $\mathrm{C}$ and $\mathrm{N}$ concentrations.

\section{Materials and methods}

\section{Study site and soil sampling}

The study site, Graswang, is a typical pre-alpine grassland ecosystem located in Southern Bavaria, Germany $\left(11.03^{\circ} \mathrm{E}\right.$, $47.57^{\circ} \mathrm{N}$ ) at an elevation of $870 \mathrm{~m}$ above sea level. This site is a part of the TERENO preAlpine long-term ecosystem observatory (Wolf et al. 2017) and has been extensively managed (Wang et al. 2016). The mean annual air temperature and precipitation were $6.9{ }^{\circ} \mathrm{C}$ and $1347 \mathrm{~mm}$, respectively, from 2014 to 2017 (Kiese et al. 2018). The investigated soil is a Cand N-rich Haplic Cambisol (IUSS Working Group WRB
2006) with a pH of 7.1 and a bulk density of $0.9 \mathrm{~g} \mathrm{~cm}^{-3}$. The topsoil (Ah horizon, $0-20 \mathrm{~cm}$ ) consists of $10 \%$ sand, $68 \%$ silt, and $23 \%$ clay with a soil organic carbon (SOC) of $89 \mathrm{mg} \mathrm{g}^{-1}$ and total nitrogen (TN) of $8.0 \mathrm{mg} \mathrm{g}^{-1}$ (Unteregelsbacher et al. 2013). Further information can be found in Unteregelsbacher et al. (2013) and Wang et al. (2016).

For the experiments, approximately $50 \mathrm{~kg}$ surface soils $(0$ $20 \mathrm{~cm}$ ) were collected in October 2014 at six sampling spots. The soil samples were homogenized and sieved ( $5 \mathrm{~mm}$ mesh) and stored at $4.0^{\circ} \mathrm{C}$ for 3 weeks until the start of the freezethaw experiments to allow an adaptation of the soil microbiome to cold temperatures. To investigate the effects of soil moisture and fertilization, soil samples were equally separated into three treatments. For the first and second treatment, the soil moisture was adjusted to $40 \%$ and $80 \%$ waterfilled pore space (40\% WFPS and $80 \%$ WFPS), respectively, whereas the third group ( $80 \%$ WFPS + F) was fertilized with cow slurry (20 mg N kg${ }^{-1}$ dry soil), representing a typical autumn slurry-N addition of $36 \mathrm{~kg} \mathrm{~N}^{-1}$, and then adjusted to $80 \%$ WFPS. The TN contents of the cow slurry were $48.1 \mathrm{~g}$ $\mathrm{N} \mathrm{kg}^{-1}$ dry mass and $2.5 \mathrm{~g} \mathrm{~N} \mathrm{~kg}^{-1}$ fresh mass with $\mathrm{NH}_{4}{ }^{+}-\mathrm{N}$ contributing $55 \%$ to total $\mathrm{N}$. The slurry had a $\mathrm{C} / \mathrm{N}$ ratio of 8.2:1 and a $\mathrm{pH}$ of 7.4 (i.e., only slightly higher than soil $\mathrm{pH}$ of 7.1). The incorporation procedure mimicked a modern slurry injection application, which is increasingly applied to reduce $\mathrm{N}$ losses, rather than traditional surface application. In Germany, the fertilizer ordinance law requires that surface slurry application is entirely replaced by incorporation techniques by the year 2025. Soils from each treatment were split in two parts. One part of the soil was placed in glass bottles (159 samples for each treatment with three replicates, $50 \mathrm{~g}$ soil per bottle) for destructive soil chemical and microbial analyses, whereas the remaining soil (ca. $6 \mathrm{~kg}$ of each treatment) was packed in four soil cores ( $15 \mathrm{~cm}$ height, $12.5 \mathrm{~cm}$ diameter) and compacted to the original bulk density of $0.9 \mathrm{~g} \mathrm{~cm}^{-3}$. Finally, cores were inserted in the helium-soil-core incubation system for automated direct measurements of $\mathrm{N}_{2} \mathrm{O}$ and $\mathrm{N}_{2}$ production (Butterbach-Bahl et al. 2002; Wang et al. 2011).

\section{Soil incubation experiments}

Bottles with soil samples for destructive analysis were placed in incubators (Thermo Electron LED BK 700, GmbH, Germany) to maintain constant temperature levels and to simulate FTCs. The air within the incubator was exchanged with outside air by a pump to avoid gas accumulation and temperature heterogeneities. Three FTCs (during approx. 16 weeks) were used to measure the effects of sequential FTCs on the abundance and activity of nitrifiers and denitrifiers and the associated $\mathrm{N}_{2} \mathrm{O}$ and $\mathrm{N}_{2}$ fluxes. The temperature in the first FTC was set to $-5{ }^{\circ} \mathrm{C}$ for 2 weeks and then to $+5{ }^{\circ} \mathrm{C}$ for 2 weeks. Topsoil temperatures of $-5^{\circ} \mathrm{C}$ are observed at the 
field site under winter conditions when no or little snow is covering the soil, but in some years are prevented by thick snow cover. The second and third freezing cycles $\left(-5^{\circ} \mathrm{C}\right)$ lasted for 4 weeks, followed by thawing at $+5^{\circ} \mathrm{C}$ for 2 weeks. To investigate the effect of temperature near the freezing point during thawing on $\mathrm{N}_{2} \mathrm{O}$ and $\mathrm{N}_{2}$ fluxes and the abundance and activity of nitrifiers and denitrifiers, the temperature during the third thawing was set to $0{ }^{\circ} \mathrm{C}$ for 3 days after 4 weeks at $-5^{\circ} \mathrm{C}$ followed by $+5{ }^{\circ} \mathrm{C}$ for 1 week (Fig. 1).

The abundance (DNA) and activity (mRNA) of nitrifiers and denitrifiers, the concentrations of soil exchangeable $\mathrm{NH}_{4}{ }^{+}, \mathrm{NO}_{3}{ }^{-}$, dissolved organic carbon (DOC) and $\mathrm{N}$ $(\mathrm{DON})$, as well as microbial biomass carbon (MBC) and
$\mathrm{N}(\mathrm{MBN})$, were determined by destructive harvesting of triplicate bottles at several time points during each FTC to identify controls of $\mathrm{N}$ gas fluxes. The soil exchangeable $\mathrm{NH}_{4}{ }^{+}, \mathrm{NO}_{3}{ }^{-}, \mathrm{DOC}$, and DON concentrations and $\mathrm{MBC}$ and $\mathrm{MBN}$ were measured with different temporal resolution during the first two FTCs: (1) once per week or biweekly during the soil freezing periods, (2) twice per day (9:00 in the morning and 16:00 in the afternoon) during the first week after thawing, and (3) daily during the second week after thawing. During the third FTC, these parameters were quantified every 2 days after thawing (Fig. $1)$. The abundance and activity of nitrifiers and

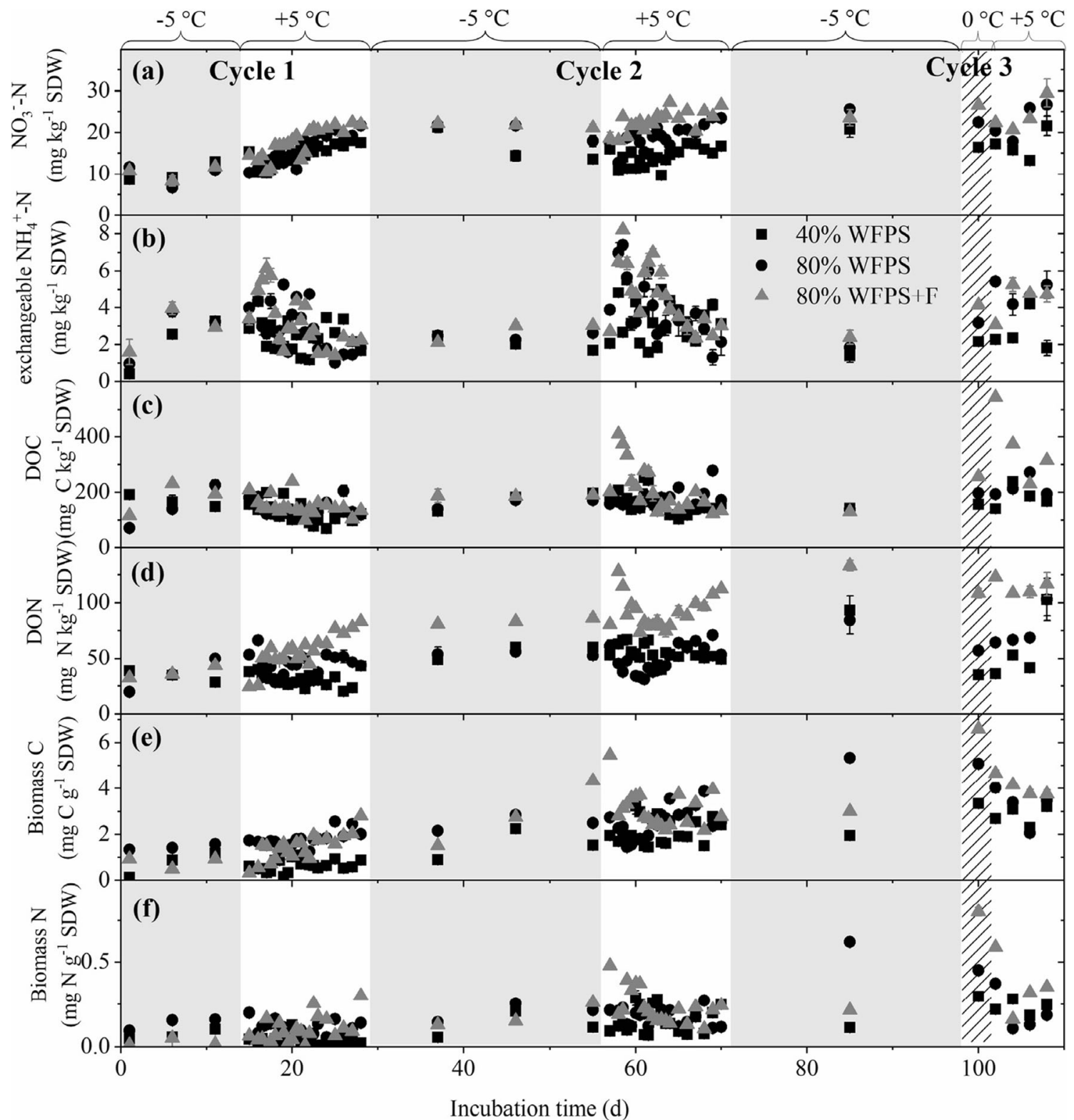

Fig. 1 Dynamics of soil $\mathrm{NO}_{3}^{-}$(a), exchangeable $\mathrm{NH}_{4}{ }^{+}(\mathbf{b}), \mathrm{DOC}(\mathbf{c})$, and DON (d) contents and microbial biomass $\mathrm{C}(\mathbf{e})$, and $\mathrm{N}(\mathbf{f})$ during the freeze-thaw cycles of different treatments. WFPS: water filled pore space;
F: fertilization with cow slurry; SDW: soil dry weight. Gray color indicates freezing periods, the shaded area is indicating incubation at $0{ }^{\circ} \mathrm{C}$ 


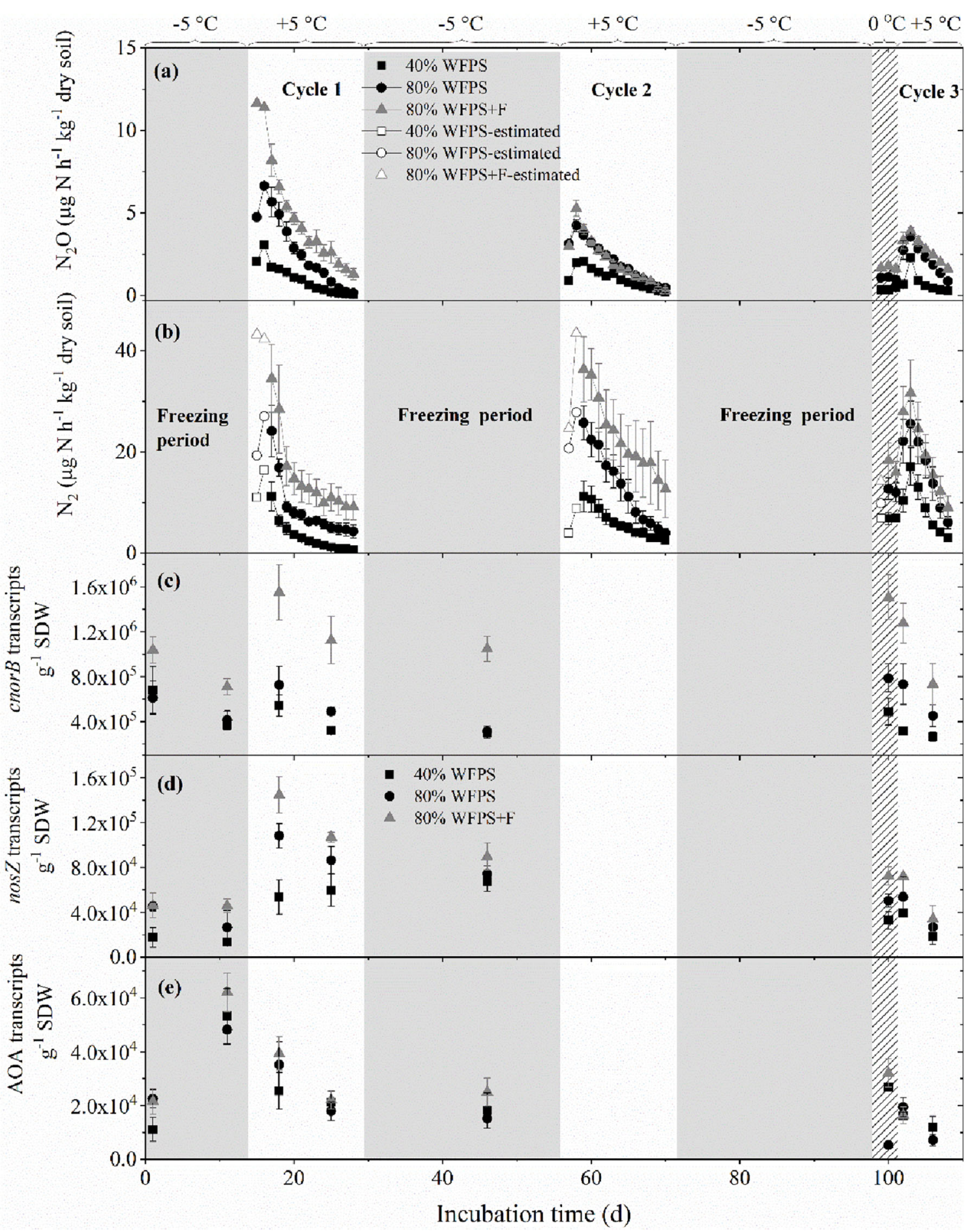

Fig. 2 Dynamics of $\mathrm{N}_{2} \mathrm{O}$ (a) fluxes, $\mathrm{N}_{2}$ (b) fluxes $(N=4)$, gene expression of $\operatorname{cnorB}$ (c), nosZ clade I (d), and AOA (e) (RNA level, $N=3$ ) during the freeze-thaw cycles of different treatments. WFPS: water

denitrifiers were detected at eight defined time intervals across the entire incubation period (Fig. 2).

The same incubation scheme was applied in parallel for the soil cores used for $\mathrm{N}_{2}$ and $\mathrm{N}_{2} \mathrm{O}$ gas flux measurements. However, because we experienced problems running the helium soil core system at $-5{ }^{\circ} \mathrm{C}$, the soil cores were stored filled pore space; F: fertilization with cow slurry; SDW: soil dry weight. Gray color indicates freezing periods, the shaded area is indicating incubation at $0{ }^{\circ} \mathrm{C}$

during the freezing periods in freezers and then were transferred in frozen form into the He system. Direct measurements of $\mathrm{N}_{2} \mathrm{O}$ and $\mathrm{N}_{2}$ fluxes were thus started with daily temporal resolution after introducing frozen soil to the He system for subsequent $\mathrm{N}$ gas flux measurements at $5{ }^{\circ} \mathrm{C}$ (first two cycles) or $0{ }^{\circ} \mathrm{C}$ (third cycle). Consequently, no measurements are 
available for the freeze phase, where emissions are assumed to be low. As only four vessels were available for simultaneous measurements by the helium soil core system, an alternating incubation scheme was used to fully use the capacities of the system (see Fig. S1).

\section{$\mathrm{N}_{2} \mathrm{O}$ and $\mathrm{N}_{2}$ flux analysis}

The $\mathrm{N}_{2} \mathrm{O}$ and $\mathrm{N}_{2}$ fluxes were measured during each thawing period over the three FTCs using an automated helium-soilcore incubation system (Butterbach-Bahl et al. 2002; Wang et al. 2011). The basic measurement principle is the exchange of $\mathrm{N}_{2}$ gas by helium in an extremely gastight soil-headspace system so that biological $\mathrm{N}_{2}$ production then can be precisely measured without the disturbing atmospheric $\mathrm{N}_{2}$ background. For this purpose, the vessels containing the soil are purged with He-based gas mixture until full $\mathrm{N}_{2}$ removal. After purging, the system switches to a static chamber mode to detect $\mathrm{N}_{2}$ and $\mathrm{N}_{2} \mathrm{O}$ concentration increases in the constant gas volume of the headspace and thus to measure soil $\mathrm{N}_{2}$ and $\mathrm{N}_{2} \mathrm{O}$ emissions. The system contains four vessels for soil cores of $12.5 \mathrm{~cm}$ diameter and $15 \mathrm{~cm}$ height, in which both soil and headspace air at approximately background composition are replaced by a synthetic atmosphere of $20 \% \mathrm{O}_{2}$ (purity grade of 5.5), $80 \% \mathrm{He}$ (purity grade of 5.0), $\mathrm{N}_{2} \mathrm{O}$ (400 ppbv), and $\mathrm{N}_{2}$ ( 25 ppmv). The small $\mathrm{N}_{2}$ background of $25 \mathrm{ppmv}$ is artificially established at the end of the exchange procedure in order to start $\mathrm{N}_{2}$ measurements with well detectable concentrations. Quantitative exchange of atmospheric background in soil and headspace with synthetic background was achieved by repeated pressure reduction to 700 mbar in the vessels containing the soil, followed by purging with the He gas mixture from the bottom of the soil cores to the headspace above the soil cores. The extreme tightness of the system against intrusion of atmospheric $\mathrm{N}_{2}$ is ensured by using double He-purged sealings, by submerging vessels and all tubing connections under water and by placing all valves, sample loops, and system control units in a He-flushed gastight box. In this study, the background exchange period started with 48 evacuation/ purging cycles within the first $24 \mathrm{~h}$, followed by $24 \mathrm{~h}$ of pure purging from bottom to top of soil cores without evacuation. The successful removal of $\mathrm{N}_{2}$ from the soil core with this procedure was confirmed by a conservative calculation of the remaining $\mathrm{N}_{2}$ concentration within the soil cores, which is described in the Supplementary Materials \& Methods.

During the entire incubation period, temperature levels were controlled by a water/glycol bath that contains the incubation vessels. The measurement of $\mathrm{N}_{2} \mathrm{O}$ fluxes started $1 \mathrm{~h}$ after closing the vessels during thawing, whereas the measurements of $\mathrm{N}_{2}$ fluxes began $48 \mathrm{~h}$ after closing the vessels because, as outlined above, this was the time required to completely exchange the atmospheric background (especially $\mathrm{N}_{2}$ ) with the synthetic background. Thus, the missing values of $\mathrm{N}_{2}$ flux during the initial stages after thawing were estimated using the measured $\mathrm{N}_{2} \mathrm{O}$ flux values and the most closely available $\mathrm{N}_{2} / \mathrm{N}_{2} \mathrm{O}$ ratios (Fig. 2). An electron capture detector (ECD, Shimadzu, Germany) and a pulse discharge He ionization detector (PDHID, Vici AG, Switzerland) were used for the detection of $\mathrm{N}_{2} \mathrm{O}$ and $\mathrm{N}_{2}$, respectively. Further information about the setup of the system, replacement of soil atmosphere, and the calculation of fluxes can be found in previous publications (Butterbach-Bahl et al. 2002; Wang et al. 2011; Chen et al. 2015; Wen et al. 2016).

\section{Analysis of abundance and activity of nitrifers and denitrifers}

Soils for molecular analyses were immediately frozen at $80^{\circ} \mathrm{C}$ after sampling. DNA and RNA were co-extracted from $0.4 \mathrm{~g}$ homogenized dry soil using the method described by Lueders et al. (2004) and the Precellys 24 Instrument (Peqlab, Erlangen, Germany). The quality and quantity of the nucleic acids were assessed using a spectrophotometer (Nanodrop; PeqLab, Germany) and agarose $(1.5 \%(w / v))$ gel electrophoresis. Afterwards, the extract was divided into two subsamples. One was used for DNA analysis and the other subsample was used to prepare RNA by digestion and purification with DNase Max kit (MO BIO Laboratories, Carlsbad, CA, USA). The absence of DNA in the RNA samples was confirmed by performing a 16S PCR reaction, using the universal eubacterial primers $968 \mathrm{f}\left(5^{\prime}\right.$-aac gcg aag aac ctt ac- $\left.3^{\prime}\right)$ and $1401 \mathrm{r}\left(5^{\prime}\right.$ cgg tgt gta caa gac cc- $\left.3^{\prime}\right)$. The cDNA was synthesized with the "High capacity cDNA reverse transcription kit" (Life Technologies, Darmstadt, Germany) according to the instructions. The success of cDNA synthesis was confirmed by performing PCR targeting the 16S rRNA gene as described above. Both DNA and cDNA extracts were stored at $-20{ }^{\circ} \mathrm{C}$ until use.

Quantitative real-time PCR (qPCR) was carried out on a 7300 real-time PCR system (Life Technologies, Darmstadt, Germany) using SYBR green as a fluorescent dye. Primer sets and plasmids containing the targeted gene fragments and PCR reaction mixtures, and thermal profiles for each gene are shown in supplementary Table S1. Dilution series of the different DNA extracts were tested in a pre-experiment with randomly picked soils to avoid inhibition of PCR. Dilutions of the DNA extracts of 1: 80 turned out to be most suitable and were used for all qPCRs. The standard curves for all the detected genes were created using 10 -fold dilution series $\left(10^{1} \sim 10^{7}\right.$ copies) of the respective plasmids containing the targeted gene fragments. All PCR runs started with an initial enzyme activation step performed at $95^{\circ} \mathrm{C}$ for $10 \mathrm{~min}$ followed by gene specific thermal profiles (Table $\mathrm{S} 1$ ), and a melting curve, consisting of $95{ }^{\circ} \mathrm{C}$ for $15 \mathrm{~s}, 60^{\circ} \mathrm{C}$ for $30 \mathrm{~s}$, and a subsequent temperature increase up to $95^{\circ} \mathrm{C}$ with a ramp rate of $0.03{ }^{\circ} \mathrm{C} \mathrm{s}^{-1}$. Specificity of the amplified products was 
checked by the observation of a single melting peak and the presence of a unique band of the expected size in a $2 \%$ agarose gel. PCR efficiencies (Eff) were calculated from the standard curve by the formula $\mathrm{Eff}=\left[10^{(-1 / \mathrm{slope})}-1\right] \times 100 \%$ and accounted for 91 to $94 \%$ for 16 SrRNA gene, $99 \%$ for nirK gene, $91 \%$ for nirS gene, $87 \%$ for cnorB gene, 91 to $96 \%$ for $n o s Z$ clade I gene, $90 \%$ for amoA AOA gene, and $91 \%$ for amo $A$ AOB gene. The $\mathrm{N}_{2} \mathrm{O}$ reductase, encoded by the nos $Z$ gene, has two major clades: clades I and II (Jones et al. 2013). As an earlier study using the same soil found very high explanatory power of nos $Z$ clade I transcripts for $\mathrm{N}_{2}$ emissions, (Chen et al. 2015) and because this study focused on nitrifiers and denitrifiers, only nos $Z$ clade I genes were considered. Clade II harbors many non-denitrifying $\mathrm{N}_{2} \mathrm{O}$ reducers (Hallin et al. 2018).

\section{Soil analyses}

Gravimetric soil water content was determined by drying the soil samples at $105^{\circ} \mathrm{C}$ until constant weight. Soil WFPS was calculated from bulk density and volumetric soil moisture content using a particle density of $2.65 \mathrm{~g} \mathrm{~cm}^{-3}$. Approximately $20 \mathrm{~g}$ of soil was extracted with $50 \mathrm{ml} 0.5 \mathrm{M}$ $\mathrm{K}_{2} \mathrm{SO}_{4}$ for measuring mineral $\mathrm{N}$ (exchangeable $\mathrm{NH}_{4}{ }^{+}-\mathrm{N}$ and $\mathrm{NO}_{3}{ }^{-} \mathrm{N}$ ), DOC, and dissolved $\mathrm{TN}$ at each sampling time point as described by Dannenmann et al. (2009). Quantification of DOC was based on an infrared detector (Multi N/C 3100 TOC/TN-Analysator, Analytik Jena, Jena, Germany) (Dannenmann et al. 2009). The concentrations of exchangeable $\mathrm{NH}_{4}{ }^{+}$and $\mathrm{NO}_{3}{ }^{-}$were determined using continuous flow injection colorimetry (Skalar San plus system, Skalar Analytical B.V., Breda, Netherland) in a commercial laboratory (Landwirtschaftliches Labor Dr. Janssen, Gillersheim, Germany). Moreover, MBC and MBN contents in soil samples were measured using the chloroform fumigation-extraction method (Dannenmann et al. 2009; Wu et al. 2014).

\section{Statistical analyses}

Statistical analyses were carried out using SPSS 15.0 (SPSS Inc., Chicago, USA) and Microcal Origin 9.0 software (Origin Lab Inc., Northampton, USA). Data were checked for normal distribution using the Kolmorov-Smirnov test and for homogeneity of variances using the Levene test; data were logtransformed when necessary. Analyses of significant differences in destructively analyzed soil parameters between treatments and frost versus thaw periods were carried out using ANOVA (with LSD method) while respective analyses for $\mathrm{N}$ gas fluxes were based on repeated measures ANOVA. Linear regression analysis was used to investigate the relationships between the $\mathrm{N}$ gas fluxes and soil characteristics and associated gene abundance/expression. Differences were considered significant at $P<0.05$.

\section{Results}

\section{Chemical soil characteristics}

The dynamics of exchangeable $\mathrm{NH}_{4}{ }^{+}, \mathrm{NO}_{3}{ }^{-}$, DOC, DON, $\mathrm{MBC}$, and MBN during three FTCs are shown in Fig. 1. Generally, we found no significant differences in $\mathrm{NO}_{3}{ }^{-}$, DON, DOC as well as microbial biomass between frozen and thawing soil. Only exchangeable $\mathrm{NH}_{4}{ }^{+}$concentrations showed pronounced peaks during thawing irrespective of soil water status and thawing cycle $(P<0.05$, Fig. 1 , Table 1$)$. During the second soil freezing period, there was a significant increase of both microbial biomass $\mathrm{C}$ and $\mathrm{N}$ (Fig. 1). Both higher WFPS and fertilization increased average soil exchangeable $\mathrm{NH}_{4}{ }^{+}$and $\mathrm{NO}_{3}{ }^{-}$contents and microbial biomass throughout the entire experimental incubation, while only fertilization significantly increased DOC and DON concentrations $(P<0.05$, Table 1$)$.

\section{$\mathrm{N}_{2} \mathrm{O}$ and $\mathrm{N}_{2}$ emissions}

Thawing always triggered sharp $\mathrm{N}_{2} \mathrm{O}$ emission pulses with peak emissions (up to $12 \mu \mathrm{g} \mathrm{N} \mathrm{kg}^{-1}$ dry soil $\mathrm{h}^{-1}$ ) being observed after first few days, followed by a gradual decline of emission levels to $0-2 \mu \mathrm{g} \mathrm{N} \mathrm{kg}{ }^{-1}$ dry soil $\mathrm{h}^{-1}$ depending on treatment and number of cycles. $\mathrm{N}_{2} \mathrm{O}$ emissions showed similar levels of ca. $0-2 \mu \mathrm{g} \mathrm{N} \mathrm{kg}{ }^{-1}$ dry soil $\mathrm{h}^{-1}$ at $0^{\circ} \mathrm{C}_{\text {during the }}$ third cycle (Fig. 2). The maximal magnitude of the $\mathrm{N}_{2} \mathrm{O}$ emission pulse as well as total cumulative emissions following a FTC declined with each cycle (Fig. 2, Table 2). Both increased WFPS and fertilization significantly increased $\mathrm{N}_{2} \mathrm{O}$ emissions across the three FTC cycles (Table 2). Over the entire incubation period and for all three FTCs, increasing soil moisture from 40 to $80 \%$ WFPS and addition of slurry increased the cumulative $\mathrm{N}_{2} \mathrm{O}$ emissions by $147.0 \%$ and $41.5 \%$, respectively (Table 2).

Dinitrogen emissions showed generally similar response patterns to thawing and the different experimental manipulations, but exceeded $\mathrm{N}_{2} \mathrm{O}$ emissions by a factor of 5-30. However, in contrast to $\mathrm{N}_{2} \mathrm{O}$, the cumulative $\mathrm{N}_{2}$ emissions during the second thawing period were significantly higher than those in first thawing cycle $(P<0.05$, Table 2$)$. In particular, for the $80 \%$ WFPS + F treatment and the first two FTCs, emissions only slowly declined and hardly fell below background emission levels of ca. $0-10 \mu \mathrm{g} \mathrm{N} \mathrm{m}{ }^{-2} \mathrm{~h}^{-1}$ (Fig. 2). Over the entire incubation period including all three FTCs, increasing soil moisture from $40 \%$ to $80 \%$ WFPS and the addition of slurry increased the cumulative $\mathrm{N}_{2}$ emissions by $101.9 \%$ and $76.8 \%$, respectively (Table 2 ). The $\mathrm{N}_{2} / \mathrm{N}_{2} \mathrm{O}$ ratios 
Table 1 Average soil inorganic $\mathrm{N}$, dissolved organic carbon (DOC), and dissolved organic $\mathrm{N}$ (DON) contents and microbial biomass $\mathrm{C} / \mathrm{N}$ in different treatments and $P$ values of ANOVA on the effect of freeze-thaw events on these soil parameters

\begin{tabular}{|c|c|c|c|c|c|c|c|}
\hline Treatments & $\begin{array}{l}\mathrm{NH}_{4}^{+}-\mathrm{N} \\
\left(\mathrm{mg} \mathrm{kg}^{-1}\right. \\
\mathrm{SDW})\end{array}$ & $\begin{array}{l}\mathrm{NO}_{3}{ }^{-}-\mathrm{N} \\
\left(\mathrm{mg} \mathrm{kg}^{-1}\right. \\
\mathrm{SDW})\end{array}$ & $\begin{array}{l}\text { DOC (mg C } \\
\mathrm{kg}^{-1} \text { SDW) }\end{array}$ & $\begin{array}{l}\text { DON } \\
\left(\mathrm{mg} \mathrm{N} \mathrm{kg}^{-1}\right. \\
\text { SDW) }\end{array}$ & $\begin{array}{l}\text { Microbial biomass } \mathrm{C} \\
\left(\mathrm{mg} \mathrm{C}^{-1} \mathrm{SDW}\right)\end{array}$ & $\begin{array}{l}\text { Microbial biomass } \mathrm{N} \\
\left(\mathrm{mg} \mathrm{N} \mathrm{g}^{-1} \mathrm{SDW}\right)\end{array}$ & $\begin{array}{l}\text { Microbial } \\
\text { biomass } \mathrm{C} / \mathrm{N} \text { ra- } \\
\text { tio }\end{array}$ \\
\hline $\begin{array}{l}40 \% \\
\text { WFPS }\end{array}$ & $2.74 \pm 0.12 \mathrm{a}$ & $14.58 \pm 0.64 a$ & $149.89 \pm 5.55 \mathrm{a}$ & $45.09 \pm 2.83 \mathrm{a}$ & $1.51 \pm 0.05 \mathrm{a}$ & $0.11 \pm 0.01 \mathrm{a}$ & $21.98 \pm 8.30 \mathrm{a}$ \\
\hline $\begin{array}{l}80 \% \\
\text { WFPS }\end{array}$ & $3.40 \pm 0.27 b$ & $17.61 \pm 0.92 b$ & $159.19 \pm 5.98 \mathrm{a}$ & $49.12 \pm 3.35 a$ & $2.28 \pm 0.07 b$ & $0.16 \pm 0.01 \mathrm{~b}$ & $16.22 \pm 3.77 \mathrm{a}$ \\
\hline $\begin{array}{l}80 \% \\
\text { WFPS + } \\
\text { F }\end{array}$ & $3.83 \pm 0.19 c$ & $20.12 \pm 1.23 \mathrm{c}$ & $195.23 \pm 7.31 b$ & $76.98 \pm 4.22 b$ & $2.43 \pm 0.06 c$ & $0.18 \pm 0.01 b$ & $20.26 \pm 3.67 \mathrm{a}$ \\
\hline \multicolumn{8}{|c|}{$P$ (freeze thaw) } \\
\hline $\begin{array}{l}40 \% \\
\text { WFPS }\end{array}$ & 0.041 & 0.864 & 0.256 & 0.250 & 0.448 & 0.770 & 0.242 \\
\hline $\begin{array}{l}80 \% \\
\text { WFPS }\end{array}$ & 0.066 & 0.523 & 0.608 & 0.821 & 0.589 & 0.035 & 0.033 \\
\hline $\begin{array}{l}80 \% \\
\text { WFPS } \\
+\mathrm{F}\end{array}$ & 0.048 & 0.065 & 0.555 & 0.515 & 0.355 & 0.201 & 0.165 \\
\hline
\end{tabular}

Values are means with standard errors. Different letters indicate significant differences among three treatments $(P<0.05, N=3$ ). $P$ (freeze thaw) is providing results of ANOVA analyses on significance of freeze-thaw events on soil parameters with significant effects being highlighted in italics $(P<0.05)$

WFPS water filled pore space, $F$ fertilization with cow slurry, $S D W$ soil dry weight

gradually increased during the first thawing period for all three treatments, while an increase of $\mathrm{N}_{2} / \mathrm{N}_{2} \mathrm{O}$ ratios during the second thawing period was only observed from the $80 \%$ WFPS + F treatment (Fig. 3a). The $\mathrm{N}_{2} /\left(\mathrm{N}_{2}+\mathrm{N}_{2} \mathrm{O}\right)$ ratios were rather stable with values of $0.7-0.92$, irrespective of different soil moisture and fertilization treatments (Fig. 3b).

Cumulative $\mathrm{N}$ gas emissions from our lab study were used to provide an approximation of $\mathrm{N}$ emissions due to slurry incorporation. Comparing the cumulative $\mathrm{N}$ gas emissions from the $80 \%$ WFPS with the $80 \%$ WFPS + F treatments revealed additional $\mathrm{N}$ losses of 0.85 and $8.98 \mathrm{mg} \mathrm{N} \mathrm{kg}^{-1}$ dry soil as $\mathrm{N}_{2} \mathrm{O}$ and $\mathrm{N}_{2}$ due to the fertilization, respectively (Table 2). These are corresponding to $4 \%$ and $45 \%$ of the applied slurry-N (20 mg N kg${ }^{-1}$ dry soil or $36 \mathrm{~kg} \mathrm{~N} \mathrm{ha}^{-1}$ ), i.e., 1.5 and $16.2 \mathrm{~kg} \mathrm{~N} \mathrm{ha}^{-1}$ during the incubation period of ca 3.5 months.

\section{Abundance and activity of nitrifiers and denitrifiers}

To improve the understanding of the role of nitrifers and denitrifers for $\mathrm{N}$ gas fluxes during FTCs, the abundance and expression of functional genes involved in nitrification and denitrification were quantified. In general, the genetic potential (based on the abundance levels of the investigated genes) was not significantly affected by FTCs (Fig. S2). In many cases, the abundance even tended to decrease in thawing compared to frozen soil (Fig. S2). In contrast, the dynamics of the related transcription exhibited remarkable temporal dynamics and treatment responses, i.e., transcripts of $\operatorname{cnor} B$ and nos $Z$ clade I showed pronounced increases in response to both slurry application and increased WFPS, which were similar to the effects observed for gaseous $\mathrm{N}$ emissions (Fig. 2). Furthermore, transcripts of these genes showed a pronounced increase due to thawing, despite we failed to sample during the

Table 2 Cumulative soil $\mathrm{N}_{2} \mathrm{O}$ and $\mathrm{N}_{2}$ fluxes during the three freeze-thaw cycles of different treatments

\begin{tabular}{|c|c|c|c|c|c|c|c|c|}
\hline \multirow[t]{2}{*}{ Treatments } & \multicolumn{4}{|c|}{ Cumulative $\mathrm{N}_{2} \mathrm{O}$ flux (mg N kg${ }^{-1} \mathrm{SDW}$ ) } & \multicolumn{4}{|c|}{ Cumulative $\mathrm{N}_{2}$ flux ( $\mathrm{mg} \mathrm{N} \mathrm{kg}^{-1} \mathrm{SDW}$ ) } \\
\hline & Cycle 1 & Cycle 2 & Cycle 3 & Three cycles & Cycle 1 & Cycle 2 & Cycle 3 & Three cycles \\
\hline $40 \%$ WFPS & $0.33 \pm 0.02 \mathrm{a}$ & $0.34 \pm 0.03 \mathrm{a}$ & $0.16 \pm 0.01 \mathrm{a}$ & $0.83 \pm 0.05 \mathrm{a}$ & $1.72 \pm 0.17 \mathrm{a}$ & $2.07 \pm 0.34 \mathrm{a}$ & $2.00 \pm 0.34 \mathrm{a}$ & $5.79 \pm 0.84 \mathrm{a}$ \\
\hline $80 \%$ WFPS & $0.90 \pm 0.08 \mathrm{~b}$ & $0.70 \pm 0.06 b$ & $0.45 \pm 0.05 b$ & $2.05 \pm 0.19 b$ & $2.98 \pm 0.31 b$ & $5.02 \pm 0.93 b$ & $3.69 \pm 0.91 b$ & $11.69 \pm 2.13 b$ \\
\hline $80 \%$ WFPS + F & $1.64 \pm 0.09 \mathrm{c}$ & $0.71 \pm 0.05 b$ & $0.55 \pm 0.04 \mathrm{c}$ & $2.90 \pm 0.18 \mathrm{c}$ & $6.72 \pm 0.98 \mathrm{c}$ & $9.56 \pm 1.82 \mathrm{c}$ & $4.39 \pm 1.06 \mathrm{c}$ & $20.67 \pm 3.85 c$ \\
\hline
\end{tabular}

Values are means with standard errors. Different letters indicate significant differences among three treatments $(P<0.05, N=4)$

WFPS water filled pore space, $F$ fertilization with cow slurry, $S D W$ soil dry weight 


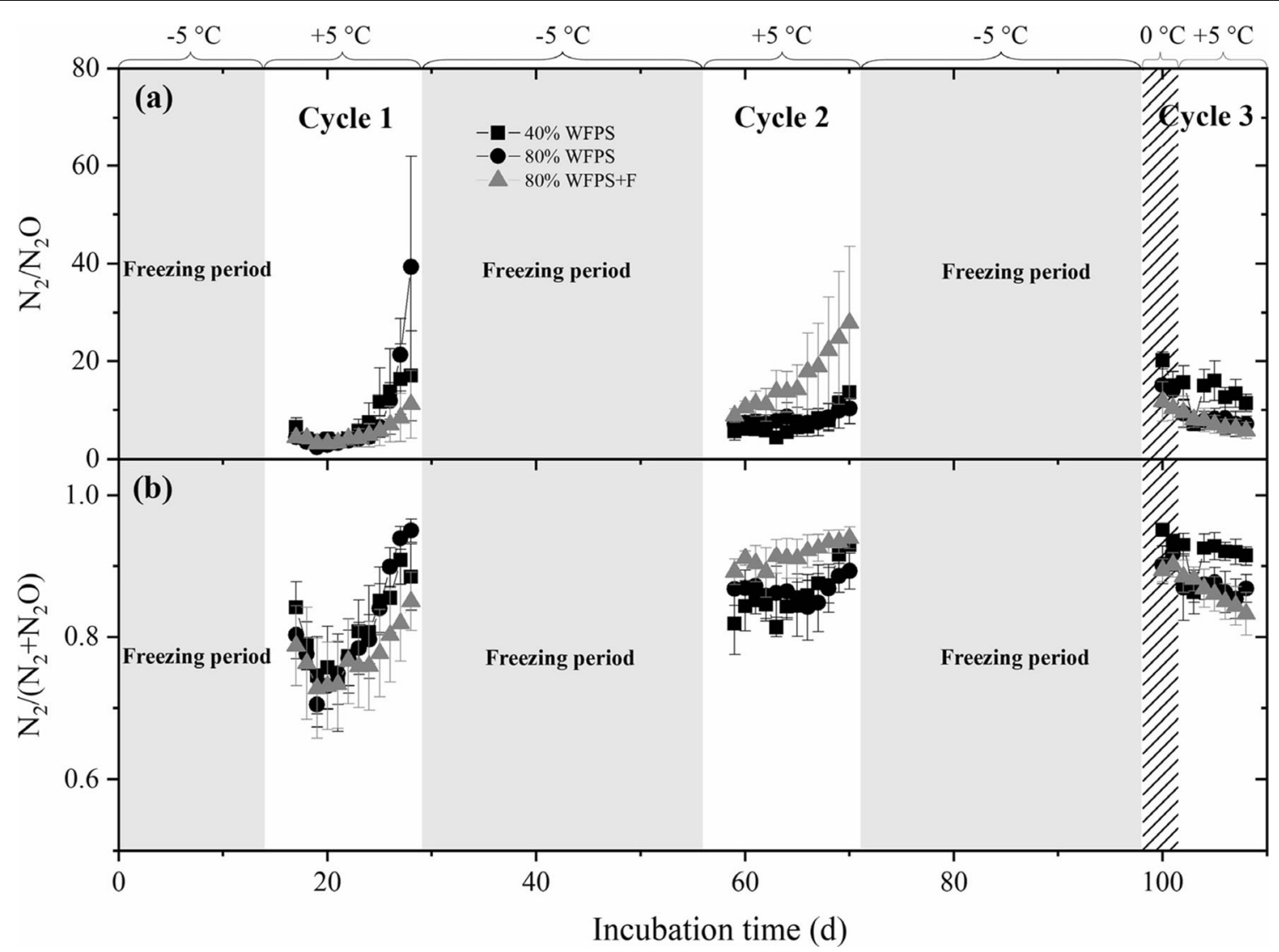

Fig. 3 Dynamics of $\mathrm{N}_{2} / \mathrm{N}_{2} \mathrm{O}$ (a) and $\mathrm{N}_{2} /\left(\mathrm{N}_{2}+\mathrm{N}_{2} \mathrm{O}\right.$ ) (b) ratios during the freeze-thaw cycles of different treatments. WFPS: water filled pore space; F: fertilization with cow slurry. Gray color indicates freezing periods, the shaded area is indicating incubation at $0{ }^{\circ} \mathrm{C}$

peak gaseous $\mathrm{N}$ emissions (Fig. 2). The number of transcripts for the archaeal amoA gene also strongly increased during the first freeze period (Fig. 2). In contrast, overall activity pattern of soil bacteria as indicated by the abundance of $16 \mathrm{~S}$ rRNA did not show substantial change during the three FTCs; however, slurry and water addition significantly increased the amount of $16 \mathrm{~S}$ rRNA in our study $(P<0.05$, Fig. S3).

The mRNA/DNA ratios of $c n o r B$ and nos $Z$ clade I showed generally similar temporal dynamics as observed for gene transcripts with substantially increased ratios after water and slurry addition as well as during thawing periods (Fig. S4).

\section{Relationships between gene transcripts and the associated $\mathbf{N}$ gas fluxes}

There were no significant correlations between the measured abundances of key populations driving denitrification and the associated $\mathrm{N}$ gas fluxes (data not shown). In contrast, the nos $Z$ clade I and cnorB gene transcripts showed good explanatory power for $\mathrm{N}_{2} \mathrm{O}$ and $\mathrm{N}_{2}$ emissions (Fig. 4). Specifically, $\mathrm{N}_{2} \mathrm{O}$ emissions were significantly correlated to both $\operatorname{cnor} B$ and nos $Z$ clade I transcripts $(P<0.01$, Fig. $4 \mathrm{a}, \mathrm{b})$ as well as the ratio of mRNA/DNA ratio of the respective genes $(P<0.05)$ when data from both FTC cycle 1 and 3 were analyzed. The relationship between the abundance of nos $Z$ clade I transcript and $\mathrm{N}_{2}$ emission was marginally significant when all data were used $(P=0.07)$, while the correlations were significantly improved when data were separated for single FTC $(P<0.05$, Fig. 4c).

\section{Discussion}

\section{Effect of soil moisture and temperature on $\mathrm{N}_{2} \mathrm{O}$ and $\mathrm{N}_{2}$ fluxes during FTCs}

It has been well established that FTCs can trigger $\mathrm{N}_{2} \mathrm{O}$ pulse emissions, with reported emissions ranging from ca. 10 $4200 \mu \mathrm{g} \mathrm{N}_{2} \mathrm{O}-\mathrm{N} \mathrm{m}^{-2} \mathrm{~h}^{-1}$ during FTCs (Grogan et al. 2004; Matzner and Borken 2008; Kim et al. 2012; Congreves et al. 2018). N gas pulse emissions during the thawing period after freeze events might include both the physical effects (e.g. substrate release) as well as the effect of temperature increase on enzymatic activities (Risk et al. 2013). However, field measurements of $\mathrm{N}_{2} \mathrm{O}$ emissions at the investigated site showed generally low $\mathrm{N}_{2} \mathrm{O}$ background fluxes of few $\mu \mathrm{g} \mathrm{N}$ $\mathrm{m}^{-2} \mathrm{~h}^{-1}$ with no effects of temperature changes (Unteregelsbacher et al. 2013). This might indicate that also the $\mathrm{N}$ gas flux peaks in this study were primarily attributed to freeze-thaw effects sensu stricto, i.e., to physical soil 

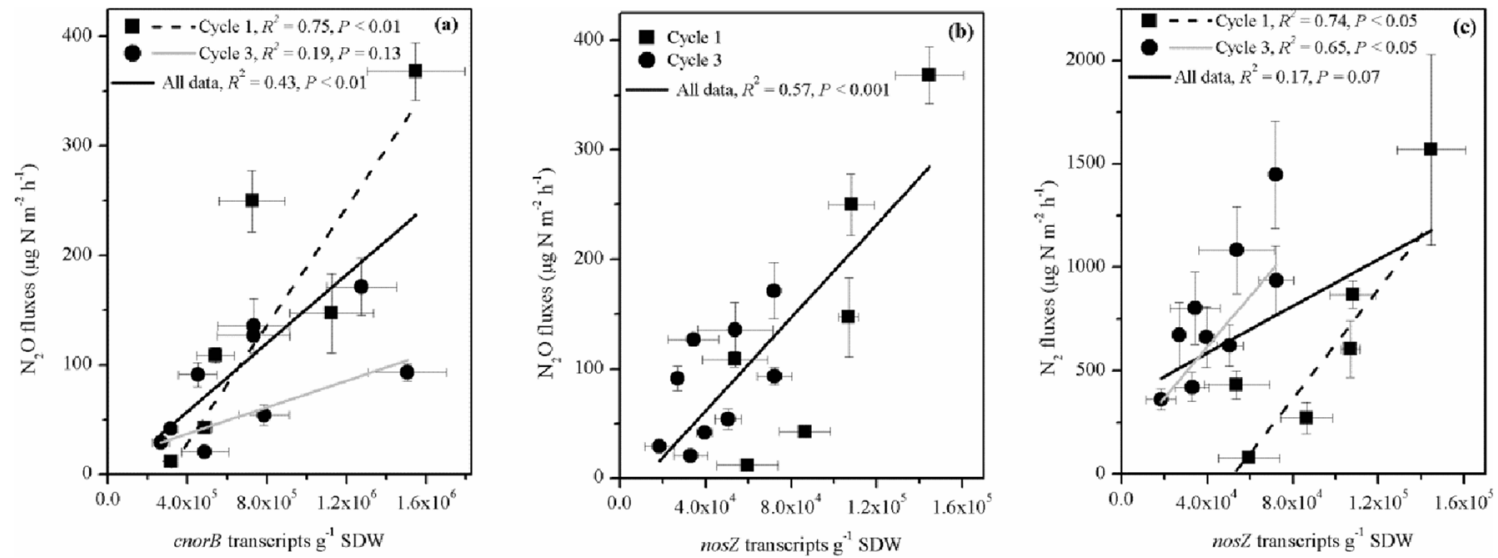

Fig. 4 Relationships between cnorB mRNA transcripts and $\mathrm{N}_{2} \mathrm{O}$ fluxes (a), between $n o s Z$ clade I mRNA transcripts and $\mathrm{N}_{2} \mathrm{O}$ fluxes (b) and between nos $Z$ clade I mRNA transcripts and $\mathrm{N}_{2}$ fluxes (c). SDW: soil dry weight

disturbance and associated substrate liberation rather than to temperature increases.

Our mechanistic study used sieved soil to improve the comparability of $\mathrm{N}$ gas emission measurements and parallel gene analyses in separate subsamples. Despite we re-packed cores to the original bulk density, sieving soil might change soil structure, and thus, distribution of water and oxygen. Furthermore, homogenization of soil might have facilitated substrate release effects but neglects plant effects on soil $\mathrm{N}$ turnover. All of this can potentially alter $\mathrm{N}$ gas fluxes. Consequently, extrapolation to field fluxes of both $\mathrm{N}_{2} \mathrm{O}$ and $\mathrm{N}_{2}$ is generally uncertain. Therefore, the $\mathrm{N}_{2} \mathrm{O}$ and $\mathrm{N}_{2}$ fluxes in this study were generally expressed on soil dry weight basis. However, when expressed on area units, maximum $\mathrm{N}_{2} \mathrm{O}$ peak emissions of $600 \mu \mathrm{g} \mathrm{N}_{2} \mathrm{O}-\mathrm{N} \mathrm{m}^{-2} \mathrm{~h}^{-1}$ are observed in this study (only first FTC, treatment $80 \%$ WFPS + slurry), while all other FTC peaks reach up to maximal values of $300 \mu \mathrm{g} \mathrm{N}$ $\mathrm{m}^{-2} \mathrm{~h}^{-1}$. Hence, the magnitude of $\mathrm{N}_{2} \mathrm{O}$ emissions reported in our study is generally in line with earlier field studies on FTC at other sites. For the investigated soil, in situ $\mathrm{N}_{2} \mathrm{O}$ emissions during FTC were not yet published.

There are only a few earlier studies on freeze-thaw $\mathrm{N}_{2}$ emissions. Applying ${ }^{15} \mathrm{~N}$ mass balance approaches to a chernozem in Alberta, Nyborg et al. (1997) indicated that a considerable fraction of the $\mathrm{N}$ lost via denitrification during spring thaw was most likely as $\mathrm{N}_{2}$. By using the ${ }^{15} \mathrm{~N}$ gas flux method to directly measure $\mathrm{N}_{2}$ during FTC, Wagner-Riddle et al. (2008) found that the patterns of $\mathrm{N}_{2}$ fluxes were similar to those of $\mathrm{N}_{2} \mathrm{O}$ fluxes during soil thawing, and the peak $\mathrm{N}_{2}$ fluxes were approximately 5-10 times higher than those of $\mathrm{N}_{2} \mathrm{O}$. Hence, our findings on FTC $\mathrm{N}_{2}$ emissions are generally in line with the very limited earlier work on that topic. Moreover, for the soils of this study, Zistl-Schlingmann et al. (2019) reported $\mathrm{N}_{2}$ emissions from intact-plant soil mesocosms of up to $2-4.5 \mathrm{mg} \mathrm{N}_{2}-\mathrm{N} \mathrm{m}^{-2} \mathrm{~h}^{-1}$ after heavy summer precipitation events. This is in the same order of magnitude as the FTC $\mathrm{N}_{2}$ emissions from disturbed soil of ca $1-2.5 \mathrm{mg} \mathrm{N} \mathrm{m}^{-2} \mathrm{~h}^{-1}$. Nonetheless, the actual extent to which results of this study are transferable to field conditions still remains uncertain.

Although it is well known that soil moisture is a key regulator of temporal variability of $\mathrm{N}_{2} \mathrm{O}$ fluxes (Wu et al. 2010; Friedl et al. 2016; Kuang et al. 2019), only little is known about the effect of soil moisture on $\mathrm{N}_{2} \mathrm{O}$ fluxes during FTCs, and reported results are controversial (Wu et al. 2014). On the one hand, increased freeze-thaw-related $\mathrm{N}_{2} \mathrm{O}$ emissions with increasing soil WFPS have been reported in previous investigations in semi-arid steppe and temperate spruce forests (Wolf et al. 2010; Wu et al. 2010). On the other hand, Teepe et al. (2004) reported that $\mathrm{N}_{2} \mathrm{O}$ emissions during thawing increased with an increase of WFPS from 42 to $64 \%$, but decreased between $64 \%$ and $76 \%$ WFPS in agricultural soils. In our study, significantly higher $\mathrm{N}_{2} \mathrm{O}$ emissions were observed at $80 \%$ compared to $40 \%$ WFPS. Enhanced microbial metabolism by substrate supply due to ice-induced physical soil disturbance has been discussed as a reason for the higher $\mathrm{N}_{2} \mathrm{O}$ emissions at higher WFPS values, and this might also explain our observations. Soil aggregates are disrupted as a result of ice crystals expanding in pores between particles during FTCs, thereby exposing physically protected organic matter and increasing the amount of accessible substrate for $\mathrm{N}_{2} \mathrm{O}$ emissions (Grogan et al. 2004; Kim et al. 2012). This assumption is supported by our results of soil properties, which showed significantly higher soil inorganic $\mathrm{N}$ and microbial biomass $\mathrm{C} / \mathrm{N}$ contents for soils incubated at $80 \%$ WFPS as compared to soils incubated at $40 \%$ WFPS (Table 1). Moreover, higher soil moisture content might result in a higher share of anaerobic microsites in the topsoil during thawing periods, which are known to promote $\mathrm{N}_{2} \mathrm{O}$ emissions by denitrification at least to a certain extent (de Bruijn et al. 2009; Wolf et al. 2012).

In contrast to our hypothesis, the $\mathrm{N}_{2} / \mathrm{N}_{2} \mathrm{O}$ ratios did not significantly differ between the $40 \%$ and $80 \%$ WFPS treatments so that higher soil moisture promoted total 
denitrification based on both enhanced $\mathrm{N}_{2} \mathrm{O}$ and $\mathrm{N}_{2}$ emissions (Fig. 3). This indicates that $80 \%$ WFPS in combination with FTCs was not sufficient to trigger the strict anaerobicity that is required for a strong promotion of the use of $\mathrm{N}_{2} \mathrm{O}$ as alternative electron acceptor in the denitrification chain (ButterbachBahl et al. 2013). This is in agreement with previous studies reporting highest $\mathrm{N}_{2} \mathrm{O}$ emissions between $80 \%$ and $100 \%$ WFPS (Ciarlo et al. 2007; Zhu et al. 2013).

The gradually increasing $\mathrm{N}_{2} / \mathrm{N}_{2} \mathrm{O}$ ratios observed in particular during the first thawing period could be possibly related to the release of low-temperature inhibition of $\mathrm{N}_{2} \mathrm{O}$ reduction to $\mathrm{N}_{2}$ at increasing temperatures; however, the existence of such a low temperature effect on $\mathrm{N}_{2} \mathrm{O}$ reductase is controversially discussed (Risk et al. 2013). The continuously high nitrate availability of $>10 \mathrm{mg} \mathrm{N} \mathrm{kg}^{-1} \mathrm{sdw}$ (Fig. 1) indicates that the changes in electron acceptor availability might not have caused increases in $\mathrm{N}_{2} / \mathrm{N}_{2} \mathrm{O}$ ratios.

In contrast to $\mathrm{N}_{2} \mathrm{O}$, there is no earlier experimental evidence of how soil moisture affects $\mathrm{N}_{2}$ emissions during FTCs. In our study, enhanced $\mathrm{N}_{2}$ emissions with increasing soil WFPS were observed during the three FTCs, which is consistent with previous observations under unfrozen soil conditions and based on acetylene or ${ }^{15} \mathrm{~N}$ techniques on general dependence of $\mathrm{N}_{2}$ emissions on soil moisture (Ciarlo et al. 2007; Zhu et al. 2013). This matches the hypothesis of many models that the magnitude of $\mathrm{N}_{2}$ emissions during denitrification increases with increasing soil moisture (Li et al. 2000; de Bruijn et al. 2009). Furthermore, the direct $\mathrm{N}_{2}$ flux measurements in combination with molecular tools in the present work provide experimental evidence for earlier assumptions that $\mathrm{N}_{2}$ emissions by denitrification are dominating gaseous $\mathrm{N}$ losses during FTCs (Ludwig et al. 2004; Wu et al. 2010) and confirm that such $\mathrm{N}$ losses can be of significant importance for the ecosystem $\mathrm{N}$ mass balance (Nyborg et al. 1997).

\section{Relationships between abundance of activity of denitrifers and nitrifiers and the formation of $\mathrm{N}_{2} \mathrm{O}$ and $\mathrm{N}_{2}$}

Throughout our incubation assay under changing moisture and fertilization/substrate availability, we did not detect significant changes in numbers of nitrifiers and denitrifiers as indicated by the measurements of functional genes for the different processes. Such a decoupling between the genetic structure and $\mathrm{N}$ gas production estimates has been reported for soils of various ecosystems (Miller et al. 2009; Henderson et al. 2010; Yoshida et al. 2012) and confirms that regulation of processes occurs more on the level of the activity than on the level of the population size. In contrast to DNA, the mRNA levels of $\operatorname{cnor} B$ and $n o s Z$ clade I and the ratios of mRNA/DNA dynamically responded to FTCs and changes in moisture and fertilization and co-varied with corresponding $\mathrm{N}$ gas fluxes. We also detected the expression of the archaeal
amoA gene throughout the FTCs, providing evidence that both nitrification and denitrification were occurring in the FTCs. An earlier study at our field site also found that the archaea are probably triggering nitrification during winter (Wang et al. 2016). Based on both molecular data and evidence from ${ }^{15} \mathrm{~N}$ isotope pool dilution gross process studies, the latter study also reported large gross ammonification and nitrification activity in frozen soil, which is in agreement with increasing transcript levels of amoA in the first soil frost cycle in this study. However, the missing relationship between $\mathrm{N}_{2} \mathrm{O}$ and $a m o A$ expression indicates rather minor contribution of nitrification to $\mathrm{N}_{2} \mathrm{O}$ emission during the FTCs. In contrast, the dynamics in the activity of denitrifers as shown by cnor $B$ and nos $Z$ clade I transcripts with significant correlation to $\mathrm{N}_{2} \mathrm{O}$ and $\mathrm{N}_{2}$ fluxes indicates that de novo denitrification contributed strongly to the measured gaseous emissions of $\mathrm{N}_{2} \mathrm{O}$ and $\mathrm{N}_{2}$ during FTCs. Hence, our study illustrates that quantifying transcripts of genes coding for key enzymes of denitrification and nitrification are a valuable approach to explain both $\mathrm{N}_{2} \mathrm{O}$ and $\mathrm{N}_{2}$ gas fluxes during FTCs (Butterbach-Bahl et al. 2013; Chen et al. 2015). However, it has to be considered that only the "classical" nos $Z$ clade I gene was investigated, targeting mainly alpha-, beta-, and gamma-proteobacteria. Recently, a second cluster of nos $Z$ genes was described (Jones et al. 2013), encoding for enzymes which catalyze the same reaction but have less than $50 \%$ amino acid sequence similarity with type I nos $Z$ enzymes. These nos $Z$ clade II genes were found among a diverse range of bacterial and archaeal phyla (Jones et al. 2013), suggesting that not all $\mathrm{N}_{2} \mathrm{O}$ reducers were covered in the present study. Thus, consideration of clade II nos $Z$ genes could further improve the explanatory power of transcripts of denitrification genes to predict gaseous $\mathrm{N}$ losses, especially answering the question about the importance of non-denitrifying $\mathrm{N}_{2} \mathrm{O}$ reducing organisms (which often possess nos $Z$ clade II genes) for mitigating $\mathrm{N}_{2} \mathrm{O}$ emissions.

Both slurry addition and increased WFPS significantly increased the $\mathrm{N}_{2} \mathrm{O}$ and $\mathrm{N}_{2}$ fluxes, accompanied by enhanced cnor $B$ and nos $Z$ clade I expression, suggesting enhanced total denitrification. This is well in agreement with our general understanding of the response of denitrification rates to soil moisture (Braker and Conrad 2011; Butterbach-Bahl et al. 2013). As for the positive effects of slurry as fertilizer on $\mathrm{N}$ gas fluxes, there might be two potential mechanisms: (1) the substrate addition of inorganic $\mathrm{N}$ and DOC that is known to promote denitrification (Braker and Conrad 2011) and (2) the increase of microbial biomass in soil as a result of the introduced microbiome of the slurry itself, which was evident from increased levels of 16S rRNA genes immediately after slurry addition (Fig. S2a). Since the ability to denitrify is widespread among bacteria, with approx. half of the bacteria containing the $n a r G$ gene (Zumft 1997), the addition of denitrifiers by slurry might significantly matter and contribute to the $\mathrm{N}$ gas fluxes. The above two aspects could also be synergistic. 
Studies indicating a correlation between nos $Z$ abundance and/or expression and $\mathrm{N}_{2}$ emissions are rare, despite the fact that $\operatorname{nos} Z$ is the only enzyme known to date that utilizes $\mathrm{N}_{2} \mathrm{O}$ as a primary substrate (Jones et al. 2013). Henderson et al. (2010) and Dandie et al. (2011) did not detect significant relationships between nos $Z$ gene expression and $\mathrm{N}_{2} \mathrm{O}$ emissions or denitrification rates in agricultural soils. This is not surprising, considering that $n o s Z$ gene expression as a measure of gross $\mathrm{N}_{2} \mathrm{O}$ consumption and gross $\mathrm{N}_{2}$ formation may not necessarily be related to net $\mathrm{N}_{2} \mathrm{O}$ loss (Wen et al. 2016). In a study on FTCs, Németh et al. (2014) indeed found that $\mathrm{N}_{2} \mathrm{O}$ emissions were negatively related to the nos $\mathrm{Z}$ transcript levels. Consequently, nos $Z$ gene expression should be closely related to $\mathrm{N}_{2}$ production, which was demonstrated in this study for the first time during FTCs, while such a relationship had been revealed for growing season fertilization events already in our previous work (Chen et al. 2015). The fact that both cnor $B$ and nos $Z$ clade I are closely correlated to both $\mathrm{N}_{2} \mathrm{O}$ and $\mathrm{N}_{2}$ might be related to the relatively stable $\mathrm{N}_{2} \mathrm{O} / \mathrm{N}_{2}$ ratios in our study and is indicating relatively stable relationships between gross $\mathrm{N}_{2} \mathrm{O}$ soil production and net $\mathrm{N}_{2} \mathrm{O}$ emissions. The relatively stable ratios of $\mathrm{N}_{2} \mathrm{O} / \mathrm{N}_{2}$ observed during FTCs might serve to estimate in situ FTC $\mathrm{N}_{2}$ emissions based on in situ $\mathrm{N}_{2} \mathrm{O}$ monitoring during FTC events in the studied ecosystem.

\section{Effect of fertilization on $\mathrm{N}_{2} \mathrm{O}$ and $\mathrm{N}_{2}$ fluxes during FTCs}

As expected, cow slurry incorporated into montane grassland soil significantly increased $\mathrm{N}_{2} \mathrm{O}$ and $\mathrm{N}_{2}$ emissions during FTCs (Table 2). Over three FTCs in 3.5 months, the additional gaseous $\mathrm{N}$ losses in the $80 \%$ WFPS plus fertilizer treatment compared to the $80 \%$ WFPS treatment without fertilizer amounted to almost half of the added fertilizer N. This is in line with our general understanding that fertilization stimulates denitrification, especially at high soil moisture levels (Ciarlo et al. 2008; Wang et al. 2013; Pan et al. 2018).

With only $0.3 \mathrm{~kg} \mathrm{~N} \mathrm{ha}^{-1}$ year ${ }^{-1}$ background, $\mathrm{N}_{2} \mathrm{O}$ field emissions at the site analyzed are very low (Unteregelsbacher et al. 2013). Keeping in mind that a comparison of field fluxes with this incubation study based on sieved soil requires great care, the estimated $\mathrm{N}_{2} \mathrm{O}$ fertilizer emissions of ca $1.5 \mathrm{~kg} \mathrm{~N}_{2} \mathrm{O}-\mathrm{N}$ ha ${ }^{-1}$ or $4 \%$ of fertilizer $\mathrm{N}$ during FTCs observed here nonetheless point at an important role of FTC fertilizer $\mathrm{N}_{2} \mathrm{O}$ emissions for the non- $\mathrm{CO}_{2}$ greenhouse gas balance in this ecosystem. This is also confirmed by emission factor considerations, i.e., the $4 \% \mathrm{~N}_{2} \mathrm{O}$ emission factor obtained in this study is - probably due to the clayey texture - higher than the average emission factor for addition of animal slurry to agricultural soils of ca 1.2\% (Charles et al. 2017).
Increased $\mathrm{N}_{2}$ losses due to combined occurrence of manuring and FTCs will not affect atmospheric radiative forcing, but might affect the ecosystem $\mathrm{N}$ balance and fertilizer $\mathrm{N}$ use efficiency. With a potential loss of up to half of slurry $\mathrm{N}$ application, a potential maximal $\mathrm{N}_{2}$ loss of $16 \mathrm{~kg} \mathrm{~N} \mathrm{ha}^{-1}$ appears possible at a moderate autumn slurry addition of $36 \mathrm{~kg} \mathrm{~N} \mathrm{ha}^{-1}$ followed by intense FTCs. This share of slurry-N lost by $\mathrm{N}_{2}$ within 3 FTCs is slightly higher than the $\mathrm{N}_{2}$ loss of $31-42 \%$ that was detected within 2 weeks in a laboratory experiment simulating a surface slurry addition (of $50 \mathrm{~kg} \mathrm{~N} \mathrm{ha}^{-1}$ ) to the soil of this study in summer under incubation conditions of $70 \%$ WFPS and $18{ }^{\circ} \mathrm{C}$ (ZistlSchlingmann et al. 2019). Despite transferability of our findings to field conditions remain limited, our findings imply that the farmers' practice of applying slurry late in autumn could involve the risk of limited $\mathrm{N}$ use efficiency when there are several severe FTC in the subsequent winter.

\section{Conclusions}

Linking $\mathrm{N}_{2} \mathrm{O} / \mathrm{N}_{2}$ flux measurements from montane grassland soil under controlled laboratory conditions over three intense FTCs with analysis of denitrifier gene expression provided a solid mechanistic basis to conclude that FTCs can trigger pulse emissions not only of $\mathrm{N}_{2} \mathrm{O}$ but also of $\mathrm{N}_{2}$. Since freeze-thaw $\mathrm{N}_{2}$ pulse emissions exceeded those of $\mathrm{N}_{2} \mathrm{O}$ by a factor of 5-30, these $\mathrm{N}_{2}$ losses could be relevant for $\mathrm{N}$ use efficiency and ecosystem $\mathrm{N}$ mass balances. Increasing soil moisture and fertilization can strongly increase both FTC $\mathrm{N}_{2} \mathrm{O}$ and $\mathrm{N}_{2}$ emissions. To more broadly understand the relevance of FTC $\mathrm{N}_{2}$ emissions and to accurately represent them in biogeochemical models, direct field measurements of FTC $\mathrm{N}_{2}$ emissions in different ecosystems are needed, thereby also considering different freezing temperatures. This, however, still poses severe methodological challenges.

Acknowledgements We would like to thank the editor and the three anonymous reviewers for very valuable suggestions and comments improve the previous version of the manuscript.

Funding information Open Access funding provided by Projekt DEAL. This study was supported by the Helmholtz-BMBF TERENO initiative, the BMBF SUSALPS project (Contract No 031B0027A), the National Natural Science Foundation of China (41773070), and the Youth Innovation Promotion Association of the Chinese Academy of Sciences (2018056). Further funding was obtained by the DFG-FOR 2337: DASIM.

Open Access This article is licensed under a Creative Commons Attribution 4.0 International License, which permits use, sharing, adaptation, distribution and reproduction in any medium or format, as long as you give appropriate credit to the original author(s) and the source, provide a link to the Creative Commons licence, and indicate if 
changes were made. The images or other third party material in this article are included in the article's Creative Commons licence, unless indicated otherwise in a credit line to the material. If material is not included in the article's Creative Commons licence and your intended use is not permitted by statutory regulation or exceeds the permitted use, you will need to obtain permission directly from the copyright holder. To view a copy of this licence, visit http://creativecommons.org/licenses/by/4.0/.

\section{References}

Braker G, Conrad R (2011) Diversity, structure, and size of $\mathrm{N}_{2} \mathrm{O}$ producting microbial communities in soils-what matters for their functioning? Adv Appl Microbiol 75:33-70

Butterbach-Bahl K, Baggs L, Dannenmann M, Kiese R, ZechmeisterBoltenstern S (2013) Nitrous oxide emissions from soils: how well do we understand the processes and their controls? Philos Trans R Soc B 368:20130122

Butterbach-Bahl K, Willibald G, Papen H (2002) Soil core method for direct simultaneous determination of $\mathrm{N}_{2}$ and $\mathrm{N}_{2} \mathrm{O}$ emissions from forest soils. Plant Soil 240:105-116

Charles A, Rochette P, Whalen JK, Angers DA, Chantigny MH, Bertrand $\mathrm{N}$ (2017) Global nitrous oxide emission factors from agricultural soils after addition of organic amendments: a meta-analysis. Agric Ecosyst Environ 236:88-98

Chen Z, Wang C, Gschwendtner S, Willibald G, Unteregelsbacher S, Lu H, Kolar A, Schloter M, Butterbach-Bahl K, Dannenmann M (2015) Relationships between denitrification gene expression, dissimilatory nitrate reduction to ammonium and nitrous oxide and dinitrogen production in montane grassland soils. Soil Biol Biochem 87:67-77

Ciarlo E, Conti M, Bartoloni N, Rubio G (2007) The effect of moisture on nitrous oxide emissions from soil and the $\mathrm{N}_{2} \mathrm{O} /\left(\mathrm{N}_{2} \mathrm{O}+\mathrm{N}_{2}\right)$ ratio under laboratory conditions. Biol Fertil Soils 43:675-681

Ciarlo E, Conti M, Bartoloni N, Rubio G (2008) Soil $\mathrm{N}_{2} \mathrm{O}$ emissions and $\mathrm{N}_{2} \mathrm{O} /\left(\mathrm{N}_{2} \mathrm{O}+\mathrm{N}_{2}\right)$ ratio as affected by different fertilization practices and soil moisture. Biol Fertil Soils 44:991-995

Congreves KA, Wagner-Riddle C, Si BC, Clough TJ (2018) Nitrous oxide emissions and biogeochemical responses to soil freezingthawing and drying-wetting. Soil Biol Biochem 117:5-15

Dandie CE, Wertz S, Leclair CL, Goyer C, Burton DL, Patten CL, Zebarth BJ, Trevors JT (2011) Abundance, diversity and functional gene expression of denitrifier communities in adjacent riparian and agricultural zones. FEMS Microbiol Ecol 77:69-82

Dannenmann M, Simon J, Gasche R, Holst J, Naumann PS, KogelKnabner I, Knicker H, Mayer H, Schloter M, Pena R, Polle A, Rennenberg H, Papen H (2009) Tree girdling provides insight on the role of labile carbon in nitrogen partitioning between soil microorganisms and adult European beech. Soil Biol Biochem 41:16221631

de Bruijn AMG, Butterbach-Bahl K, Blagodatsky S, Grote R (2009) Model evaluation of different mechanisms driving freeze-thaw $\mathrm{N}_{2} \mathrm{O}$ emissions. Agric Ecosyst Environ 133:196-207

Felber R, Conen F, Flechard CR, Neftel A (2012) Theoretical and practical limitations of the acetylene inhibition technique to determine total denitrification losses. Biogeosciences 9:4125-4138

Fowler D, Pyle JA, Raven JA, Sutton MA (2013) The global nitrogen cycle in the twenty-first century: introduction. Philos Trans R Soc B 368:20130165

Friedl J, Scheer C, Rowlings DW, Mclntosh HV, Strazzabosco A, Warner DI, Grace PR (2016) Denitrification losses from an intensively managed sub-tropical pasture - impact of soil moisture on the partitioning of $\mathrm{N}_{2}$ and $\mathrm{N}_{2} \mathrm{O}$ emissions. Soil Biol Biochem 92:58-66
Galloway JN, Townsend AR, Erisman JW, Bekunda M, Cai Z, Freney JR, Martinelli LA, Seitzinger SP, Sutton MA (2008) Transformation of the nitrogen cycle: recent trends, questions and potential solutions. Science 320:889-892

Gao D, Zhang L, Liu J, Peng B, Fan Z, Dai W, Jiang P, Bai E (2018) Responses of terrestrial nitrogen pools and dynamics to different patterns of freeze-thaw cycle: a meta-analysis. Glob Chang Biol 24:2377-2389

Goldberg SD, Muhr J, Borken W, Gebauer G (2008) Fluxes of climaterelevant trace gases between a Norway spruce forest soil and atmosphere during repeated freeze-thaw cycles in mesocosms. J Plant Nutr Soil Sci 171:729-739

Groffman PM (2012) Terrestrial denitrification: challenges and opportunities. Ecol Process 1:11. https://doi.org/10.1186/2192-1709-1-11

Groffman PM, Altabet MA, Bohlke JK, Butterbach-Bahl K, David MB, Firestone MK, Giblin AE, Kana TM, Nielsen LP, Voytek MA (2006) Methods for measuring denitrification: diverse approaches to a difficult problem. Ecol Appl 16:2091-2122

Grogan P, Michelsen A, Ambus P, Jonasson S (2004) Freeze-thaw regime effects on carbon and nitrogen dynamics in subarctic heath tundra mesocosms. Soil Biol Biochem 36:641-654

Hallin S, Philippot L, Löffler FE, Sanford RA, Jones CM (2018) Genomics and ecology of novel $\mathrm{N}_{2} \mathrm{O}$-reducing microorganisms. Trends Microbiol 26:43-55

Henderson SJ, Dandie CE, Patten CL, Zebarth BJ, Burton DL, Trevors JT, Goyer C (2010) Changes in denitrifier abundance, denitrification gene mRNA levels, nitrous oxide emissions, and denitrification in anoxic soil microcosms amended with glucose and plant residues. Appl Environ Microbiol 76:2155-2164

Henry HAL (2008) Climate change and soil freezing dynamics: historical trends and projected changes. Clim Chang 87:421-434

IUSS Working Group WRB (2006) World reference base for soil resources (2006) World Soil Resources Report No 103. FAO, Rome

Jones CM, Graf DRH, Bru D, Philippot L, Hallin S (2013) The unaccounted yet abundant nitrous oxide-reducing microbial community: a potential nitrous oxide sink. ISME J 7:417-426

Jung J, Yeom J, Kim J, Han J, Lim HS, Park H, Hyun S, Park W (2011) Change in gene abundance in the nitrogen biogeochemical cycle with temperature and nitrogen addition in Antarctic soils. Res Microbiol 162:1018-1026

Kiese R, Fersch B, Baessler C, Brosy C, Butterbach-Bahl K, Chwala C, Dannenmann M, Fu J, Gasche R, Grote R, Jahn C, Klatt J, Kunstmann H, Mauder M, Rödiger T, Smiatek G, Soltani M, Steinbrecher R, Völksch I, Werhahn J, Wolf B, Zeeman M, Schmid HP (2018) The TERENO pre-Alpine observatory: integrating meteorological, hydrological, and biogeochemical measurements and modeling. Vadose Zone J 17:180060. https://doi.org/10. 2136/vzj2018.03.006

Kim DG, Vargas R, Bond-Lamberty B, Turetsky MR (2012) Effects of soil rewetting and thawing on soil gas fluxes: a review of current literature and suggestions for future research. Biogeosciences 9: 2459-2483

Kuang W, Gao X, Tenuta M, Gui D, Zeng F (2019) Relationship between soil profile accumulation and surface emission of $\mathrm{N}_{2} \mathrm{O}$ : effects of soil moisture and fertilizer nitrogen. Biol Fertil Soils 55:97-107

Kulkarni MV, Burgin AJ, Groffman PM, Yavitt JB (2014) Direct flux and ${ }^{15} \mathrm{~N}$ tracer methods for measuring denitrification in forest soils. Biogeochemistry 117:359-373

Kulkarni MV, Groffman PM, Yavitt JB (2008) Solving the global nitrogen problem: it's a gas! Front Ecol Environ 6:199-206

Li C, Aber J, Stange F, Butterbach-Bahl K, Papen H (2000) A processoriented model of $\mathrm{N}_{2} \mathrm{O}$ and $\mathrm{NO}$ emissions from forest soils: 1 . Model development. J Geophys Res 105:4369-4384

Ludwig B, Wolf I, Teepe R (2004) Contribution of nitrification and denitrification to the emission of $\mathrm{N}_{2} \mathrm{O}$ in a freeze-thaw event in an agricultural soil. J Plant Nutr Soil Sci 167:678-684 
Lueders T, Manefield M, Friedrich MW (2004) Enhanced sensitivity of DNA- and rRNA-based stable isotope probing by fractionation and quantitative analysis of isopycnic centrifugation gradients. Environ Microbiol 6:73-78

Matzner E, Borken W (2008) Do freeze-thaw events enhance C and N losses from soils of different ecosystems? A review. Eur J Soil Sci 59:274-284

Miller MN, Zebarth BJ, Dandie CE, Burton DL, Goyer C, Trevors JT (2009) Influence of liquid manure on soil denitrifier abundance, denitrification, and nitrous oxide emissions. Soil Sci Soc Am J 73: 760-768

Mørkved PT, Dörsch P, Henriksen TM (2006) $\mathrm{N}_{2} \mathrm{O}$ emissions and product ratios of nitrification and denitrification as affected by freezing and thawing. Soil Biol Biochem 38:3411-3420

Morse JL, Duran J, Groffman PM (2015) Soil denitrification fluxes in a Northern Hardwood Forest: the importance of snowmelt and implication for ecosystem $\mathrm{N}$ budgets. Ecosystems 18:520-532

Németh DD, Wagner-Riddle C, Dunfield KE (2014) Abundance and gene expression in nitrifier and denitrifier communities associated with a field scale spring thaw $\mathrm{N}_{2} \mathrm{O}$ flux event. Soil Biol Biochem 73: $1-9$

Nyborg M, Laidlaw JW, Solberg ED, Malhi SS (1997) Denitrification and nitrous oxide emissions from a Black Chernozemic soil during spring thaw in Alberta. Can J Soil Sci 77:153-160

Pan H, Ying S, Liu H, Zeng L, Zhang Q, Liu Y, Xu J, Li Y, Di H (2018) Microbial pathways for nitrous oxide emissions from sheep urine and dung in a typical steppe grassland. Biol Fertil Soils 54:717-730

Qu Z, Wang J, Almøy T, Bakken LR (2014) Excessive use of nitrogen in Chinese agriculture results in high $\mathrm{N}_{2} \mathrm{O} /\left(\mathrm{N}_{2} \mathrm{O}+\mathrm{N}_{2}\right)$ product ratio of denitrification, primarily due to acidification of the soils. Glob Chang Biol 20:1685-1698

Risk N, Snider D, Wagner-Riddle C (2013) Mechanisms leading to enhanced soil nitrous oxide fluxes induced by freeze-thaw cycles. Can J Soil Sci 93:401-414

Sgouridis F, Ullah S (2015) Relative magnitude and controls of in situ $\mathrm{N}_{2}$ and $\mathrm{N}_{2} \mathrm{O}$ fluxes due to denitrification in natural and seminatural terrestrial ecosystems using ${ }^{15} \mathrm{~N}$ tracers. Environ Sci Technol 49: $14110-14119$

Teepe R, Vor A, Beese F, Ludwig B (2004) Emissions of $\mathrm{N}_{2} \mathrm{O}$ from soils during cycles of freezing and thawing and the effects of soil water, texture and duration of freezing. Eur J Soil Sci 55:357-365

Unteregelsbacher S, Gasche R, Lipp L, Sun W, Kreyling O, Geitlinger H, Kogel-Knabner I, Papen H, Kiese R, Schmid H, Dannenmann M (2013) Increased methane uptake but unchanged nitrous oxide flux in montane grasslands under simulated climate change conditions. Eur J Soil Sci 64:586-596

Wagner-Riddle C, Hu QC, van Bochove E, Jayasundara S (2008) Linking nitrous oxide flux during spring thaw to nitrate denitrification in the soil profile. Soil Sci Soc Am J 72:908-916

Wang C, Chen Z, Unteregelsbacher S, Lu H, Gschwendtner S, Gasche R, Kolar A, Schloter M, Kiese R, Butterbach-Bahl K, Dannenmann M (2016) Climate change amplifies gross nitrogen turnover in montane grasslands of Central Europe in both summer and winter seasons. Glob Chang Biol 22:2963-2978

Wang R, Feng Q, Liao T, Zheng X, Butterbach-Bahl K, Zhang W, Jin C (2013) Effects of nitrate concentration on the denitrification potential of a calcic cambisol and its fractions of $\mathrm{N}_{2}, \mathrm{~N}_{2} \mathrm{O}$ and NO. Plant Soil 363:175-189
Wang R, Willibald G, Feng Q, Zheng X, Liao T, Brüggemann N, Butterbach-Bahl K (2011) Measurement of $\mathrm{N}_{2}, \mathrm{~N}_{2} \mathrm{O}$, NO and $\mathrm{CO}_{2}$ emissions from soil with the gas-flow-soil-core technique. Environ Sci Technol 45:6066-6072

Wen Y, Chen Z, Dannenmann M, Carminati A, Willibald G, Kiese R, Wolf B, Veldkamp E, Butterbach-Bahl K, Corre MD (2016) Disentangling gross $\mathrm{N}_{2} \mathrm{O}$ production and consumption in soil. Sci Rep 6:36517

Wertz S, Goyer C, Zebarth BJ, Tatti E, Burton DL, Chantigny MH, Filion M (2016) The amplitude of soil freeze-thaw cycles influences temporal dynamics of $\mathrm{N}_{2} \mathrm{O}$ emissions and denitrifier transcriptional activity and community composition. Biol Fertil Soils 52:1149-1162

Wiesmeier M, Hübner R, Barthold F, Spörlein P, Geuß U, Hangen E, Reischl A, Schilling B, von Lützow M, Kögel-Knabner I (2013) Amount, distribution and driving factors of soil organic carbon and nitrogen in cropland and grassland soils of southeast Germany (Bavaria). Agric Ecosyst Environ 176:39-52

Wolf B, Chwala C, Fersch B, Garvelmann J, Junkermann W, Zeeman MJ, Angerer A, Adler B, Beck C, Brosy C, Brugger P, Emeis S, Dannenmann M, De Roo F, Diaz-Pines E, Haas E, Hagen M, Hajnsek I, Jacobeit J, Jagdhuber T, Kalthoff N, Kiese R, Kunstmann H, Kosak O, Krieg R, Malchow C, Mauder M, Merz R, Notarnicola C, Philipp A, Reif W, Reineke S, Rödiger T, Ruehr N, Schäfer K, Schrön M, Senatore A, Shupe H, Völksch I, Wanninger C, Zacharias S, Schmid HP (2017) The scalex campaign: scale-crossing land surface and boundary layer processes in the TERENO-preAlpine observatory. Bull Am Meteorol Soc 98: $1217-1234$

Wolf B, Kiese R, Chen W, Grote R, Butterbach-Bahl K (2012) Modeling $\mathrm{N}_{2} \mathrm{O}$ emissions from steppe in Inner Mongolia, China, with consideration of spring thaw and grazing intensity. Plant Soil 350:297-310

Wolf B, Zheng X, Brüggemann N, Chen W, Dannenmann M, Han X, Sutton MA, Wu H, Yao Z, Butterbach-Bahl K (2010) Grazinginduced reduction of natural nitrous oxide release from continental steppe. Nature 464:881-884

Wu X, Brüggemann N, Butterbach-Bahl K, Fu B, Liu G (2014) Snow cover and soil moisture controls of freeze-thaw-related soil gas fluxes from a typical semi-arid grassland: a laboratory experiment. Biol Fertil Soils 50:295-306

Wu X, Brüggemann N, Gasche R, Shen Z, Wolf B, Butterbach-Bahl K (2010) Environmental controls over soil-atmosphere exchange of $\mathrm{N}_{2} \mathrm{O}$, NO and $\mathrm{CO}_{2}$ in a temperate Norway spruce forest. Glob Biogeochem Cy 24:GB2012

Yoshida M, Ishii S, Fujii D, Otsuka S, Senoo K (2012) Identification of active denitrifiers in rice paddy soil by DNA- and RNA-based analyses. Microbes Environ 27:456-461

Zhu T, Zhang J, Yang W, Cai Z (2013) Effects of organic material amendment and water content on $\mathrm{NO}, \mathrm{N}_{2} \mathrm{O}$, and $\mathrm{N}_{2}$ emissions in a nitrate-rich vegetable soil. Biol Fertil Soils 49:153-163

Zistl-Schlingmann M, Feng J, Kiese R, Stephan R, Zuazo P, Willibald G, Wang C, Butterbach-Bahl K, Dannenmann M (2019) Dinitrogen emissions: an overlooked key component of the $\mathrm{N}$ balance of montane grasslands. Biogeochemistry 143:15-30

Zumft WG (1997) Cell biology and molecular basis of denitrification. Microbiol Mol Biol Rev 61:533-616

Publisher's note Springer Nature remains neutral with regard to jurisdictional claims in published maps and institutional affiliations. 